九州大学学術情報リポジトリ

Kyushu University Institutional Repository

\title{
GIS-based Watershed Management Modeling for Surface Runoff Calculation in Tatara River Basin, Japan
}

Ix, Hour

Graduate School of Bioresource and Bioenvironmental Sciences, Kyushu University

Mori, Makito

Faculty of Agriculture, Kyushu University

Hiramatsu, Kazuaki

Faculty of Agriculture, Kyushu University

Harada, Masayoshi

Faculty of Agriculture, Kyushu University

https://doi.org/10.5109/9333

出版情報: 九州大学大学院農学研究院紀要. 52 (2)，pp.431-438，2007-10-29. Faculty of Agriculture, Kyushu University

バージョン :

権利関係 : 


\title{
GIS-based Watershed Management Modeling for Surface Runoff Calculation in Tatara River Basin, Japan
}

\author{
Hour IX ${ }^{1 *}$, Makito MORI, Kazuaki HIRAMATSU \\ and Masayoshi HARADA
}

\author{
Laboratory of Drainage and Water Environment, Division of Regional Environment Science, \\ Department of Bioproduction Environmental Sciences, Faculty of Agriculture, \\ Kyushu University, Fukuoka 812-8581, Japan \\ (Received May 16, 2007 and accepted July 17, 2007)
}

\begin{abstract}
In the past few decades when Geographical Information System (GIS) technology was not fully developed in practical use, watershed delineation work used to be conducted manually by hydrologists based on topographic maps. The work was a tedious operation, since it had to be done repeatedly in similar manner for each basin or sub-basin of interest, and its process always left some unpredicted errors. Nowadays, GIS software is being upgraded regularly with powerful tools responding to the needs of users in different fields. In the present study, to find a simple hydrological solution for a basin (Tatara River basin), an extension tool (ArcHydro) of a well-known GIS software (ArcGIS) was essentially used for simulations of elevation, drainage line definition, watershed delineation, drainage feature characterization and geometric network generation. With sufficient resolution of DEM interpolated from point elevation data, all water bodies extracted from topographic maps in the basin were critically characterized_- the depth and water volume of lakes, ponds, and rivers were numerically computed. The final goal of this paper is to calculate surface runoff of the study basin based on a GIS-based watershed management approach. The work was also processed under another extension called the ArcCN-Runoff model, which ran on the background of ArcGIS software. This extension tool was built based on a very popular model for surface runoff estimation known as the Soil Conservation Service-Curve Number (SCS-CN) model. A total discharge volume in the northern sub-watershed region of the basin was consequently computed on a monthly basis throughout one year. The computed discharges were totally consistent with those observed, and each of the discharges was also confirmed to be responsible for rainfall. These indicate that SCS-CN and ArcCN-Runoff models used in this paper are definitely valid and can be applied to other related projects of surface runoff calculation.
\end{abstract}

\section{INTRODUCTION}

In recent years, watershed has been targeted as the best planning unit for land and natural resource management due to its unique characteristics in shape, terrain visualization, geology, climate, soil, land form, and social economic point of view. Understanding of a watershed, hence, has become significantly important for making a productive use of its natural resources and prevention of environmental damages by flooding, storms, etc. These processes are integrated into a work known as 'watershed management' (Adinarayana et al., 1995).

GIS technology brings a number of strengths to water resources research, which provides a variety of important information related to watershed projects needed for the decision-making process (Hardmeyer and Spencer, 2007). The goals of many watershed studies cover the same basic tasks which include watershed segmentation, identification of drainage lines and channels network, characterization of terrain slope and aspect, catchments delineation, and water flow path (Lyon, 2003). The digital elevation model (DEM) of land-surface terrain is known as an effective source for

\footnotetext{
1 Laboratory of Drainage and Water Environment, Division of Regional Environment Science, Department of Bioproduction Environmental Sciences, Graduate School of Bioresource and Bioenvironmental Sciences, Kyushu University

* Corresponding author (E-mail: hourix2005@yahoo.com)
}

obtaining a consistent method for watershed and stream network delineation in GIS applications (Maidment, 2002; Kenny and Matthews, 2005; Soille and Ansoult, 1990).

In the present study, applications for hydrological simulation (ArcHydro and ArcCN-Runoff models) were employed to simulate runoff properties in a basin, located in northern Kyushu, Japan. Like other GIS software for watershed delineation, ArcHydro utilizes DEM as the input of the digital terrain model (DTM) to identify the surface drainage pattern. Subsequently, the DEM and its derivatives will be used to efficiently delineate watersheds and geometrically generate stream network (ESRI, 2006).

A major problem which occurs when conducting watershed and drainage network delineation is the existence of sinks in raw DEM data. The water is usually trapped in the sinks because they are surrounded by higher elevated cells (Martz and Garbrecht, 1992; Turcotte et al., 2001). Such negative results will affect the entire process of watershed delineation. To eliminate them, a tool to fill sinks was incorporated into ArcHydro so that the elevation values of sink-surrounding cells will be modified. Additionally, ArcHydro data model handles some ideal processing tasks such as "DEM Reconditioning" and "Build Walls". The reconditioning process, in particular, help DEM's surface adjust to be consistent with the vector coverage, which enables extraction of hydrographic features in more detail 
(Hellweger, 1997). These tools are known to be significantly important in watershed delineation operation as they decrease errors that often occur in DEM processing procedures and produce topographic grids highly reflecting drainage features of the projected area.

The sections presented in the following demonstrate a number of practical applications of ArcHydro tools and the ArcCN-Runoff model to solve problems for watershed management modeling in the study basin and calculate the total amount of surface runoff over the basin.

The US Soil Conservation Service-Curve Number (SCS-CN) — now the Natural Resource Conservation Service Curve Number (NRCS-CN) - method is the most common and popular method for estimating the surface runoff and peak discharge in depth from rainfall events (Zhan and Huang, 2004; Jain et al., 2006a and 2006b; Mishra et al., 2006; Terzoudi et al., 2007). In this model, curve number (CN) was regarded as the representative of a single parameter to express water retention of soil. Values for soil retention are estimated from various correlations of many factors influencing infiltration, rainfall pattern, initial soil moisture, tillage practice, physical soil properties and densities of vegetation roots and stems. Factors of surface roughness, surface storage, slope, size of watershed overland flow area, as well as rate of precipitation have also been taken into account in the model (Mack, 1995). Therefore, selection of curve numbers, which vary with soil type, land use cover and hydrologic condition of the soil, plays a vital role in the $\mathrm{CN}$ model.

Based on the above curve-number method, an ArcGIS interface extension, called ArcCN-Runoff, was then developed to facilitate the watershed modeling task. Polygon coverages of land use and soil with their hydrologic characteristics have been targeted as the input sources in order to reduce processing speed (Zhan and Huang, 2004).

In this paper, a GIS-based management work is specifically divided into two different parts: (1) terrain surface analysis and watershed delineation by ArcHydro ArcCN-Runoff and (2) surface runoff calculation by ArcCN-Runoff extension. Grid operation and its methodology, together with curve number and runoff models used in this study, will be clearly addressed.

\section{STUDY AREA}

The targeted study site is Tatara River basin, which is nearly situated in the central part of Fukuoka Prefecture (Fig. 1). The basin has a total drainage area of about $180 \mathrm{~km}^{2}$ and is divided into two sub-watershed areas. The northern part of the basin has a total area of approximately $94 \mathrm{~km}^{2}$ and has been officially determined based on the administrative boundary of Fukuoka Prefecture. Land cover of the basin indicates that 53\% of the total area is forest cover, which has an average curve number of 62 referring to the index table of ArcCN-Runoff extension software. In rainy seasons, runoff begins from the relatively higher elevated areas.
Gathered water converges or flows into the Tatara River and finally drains away to Hakata Bay in the west. Like some other regions in Japan, the basin receives the highest rainfall volume in June or July. An average precipitation in this region results in a medium level of about $1700 \mathrm{~mm}$ per year. This phenomenon has significantly contributed to a relatively high runoff volume at the outlet point of the basin annually.

\section{DATA}

The data used as initial input in this study were obtained from two main important sources: DEM and topographic maps. The former and the latter were provided by the Ministry of Land, Infrastructure and Transport (MLIT) and Geographical Survey Institute (GSI) of Japan, respectively. We also used daily data of discharge and rainfall during 2001; they were observed within the northern sub-watershed of the basin. These hydro-meteorological data were supplied from Fukuoka Prefectural Government, and will be graphed with the computed result to evaluate the performance of the model used in this study later.

\section{Digital Elevation Model (DEM)}

The resolution of DEM affects the results of watershed delineation and stream definition (Luzio et al., 2005). Referring to other methods, the highest resolution DEM $(30 \times 30 \mathrm{~m})$ data in its evaluation study provided the best estimate of watershed properties (Chaubey et al., 2005). Thus, in order to obtain a better output and to eliminate some unpredicted errors, we started the present study by launching the process with a $30 \times 30 \mathrm{~m}$ DEM input. The elevation data involved in the DEM were initially obtained by interpolating the official elevation data from MLIT using the Kriging method (Fig. 2).

\section{Hydrographic Features}

Topographic maps $(1: 25,000)$ or their electric files $(1: 50,000)$ from GSI were used as the background of the hydrographic feature extraction. All flow lines, centerlines, and shorelines were digitized into one single layer called "flowline". The boundaries of rivers, ponds, and lakes were additionally traced as a single layer named "waterbody" for its attribute characterization.

\section{METHODOLOGY}

\section{Drainage analysis using digital elevation models Flow direction grid}

Elevation values of DEM cells were computed based on an eight-direction pour point model to form an output of flow direction grid. In this method, water of a given cell is allowed to flow down to only one adjacent cell with the smallest elevation value. It is known as the direction of steepest descent (Maidment, 2002). The code numbers then are assigned to the resulting flow direction grids as follow: 1 for east, 2 for southeast, 4 for south, 8 for southwest, 16 for west, 32 for northwest, 64 


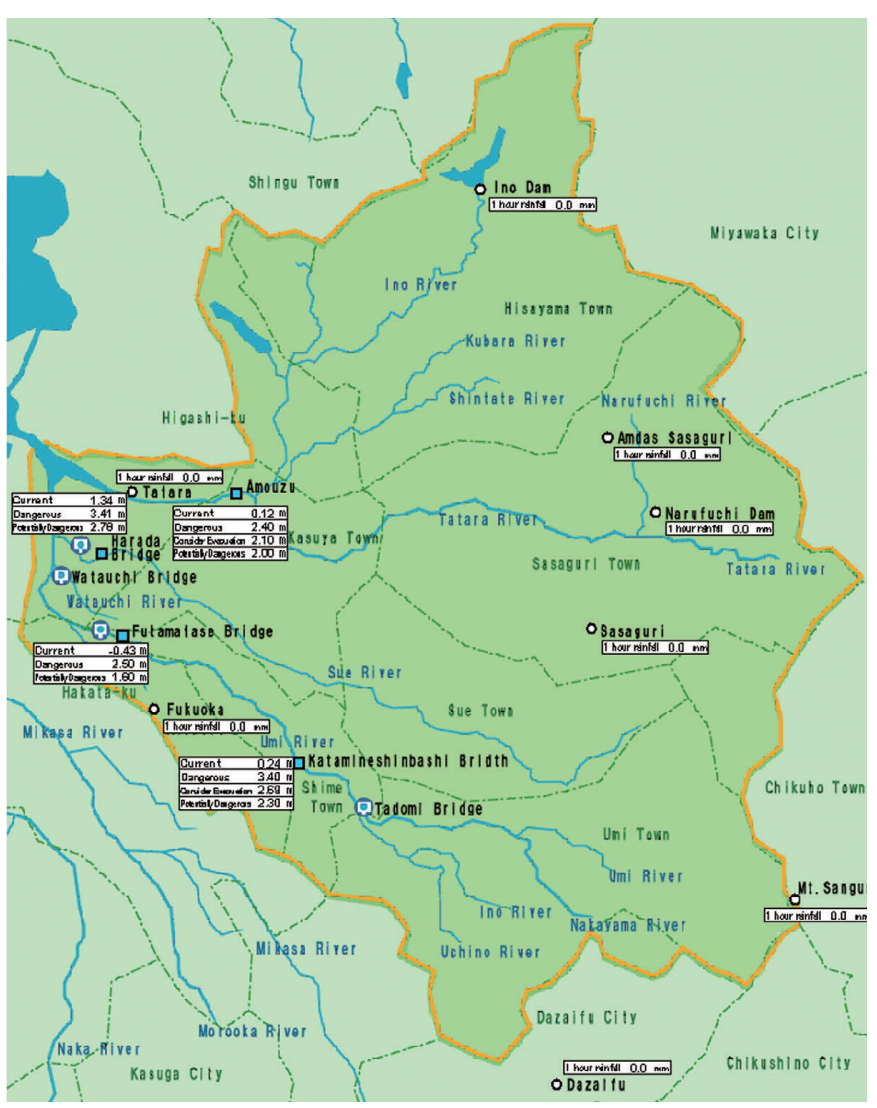

Fig. 1. Location of Tatara River basin with its surroundings. (Fukuoka Citizen Bureau, 2007)

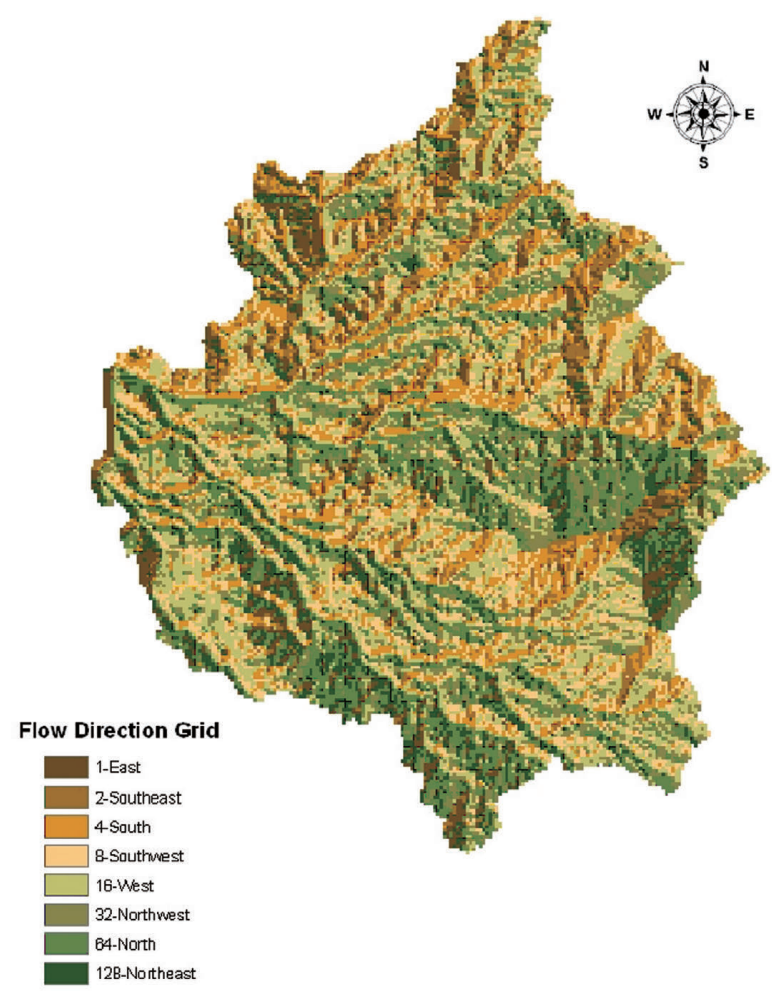

Fig. 3. Flow direction grid (8-direction pour point method).

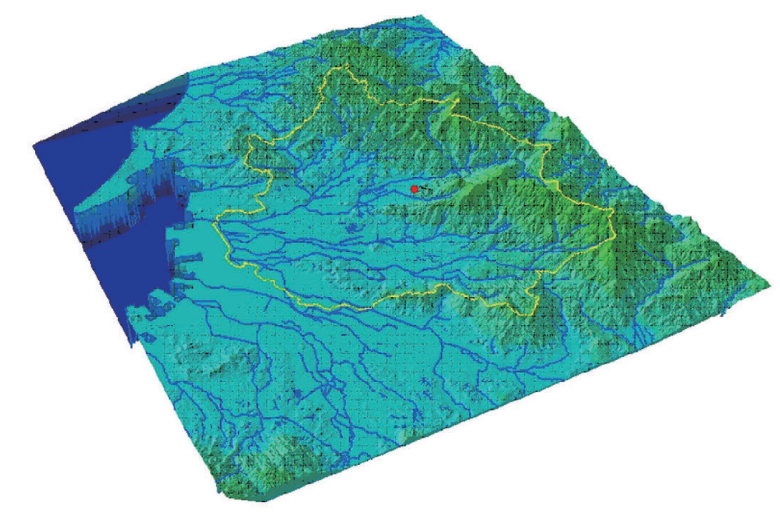

Fig. 2. DEM 3D view of Tatara River basin.

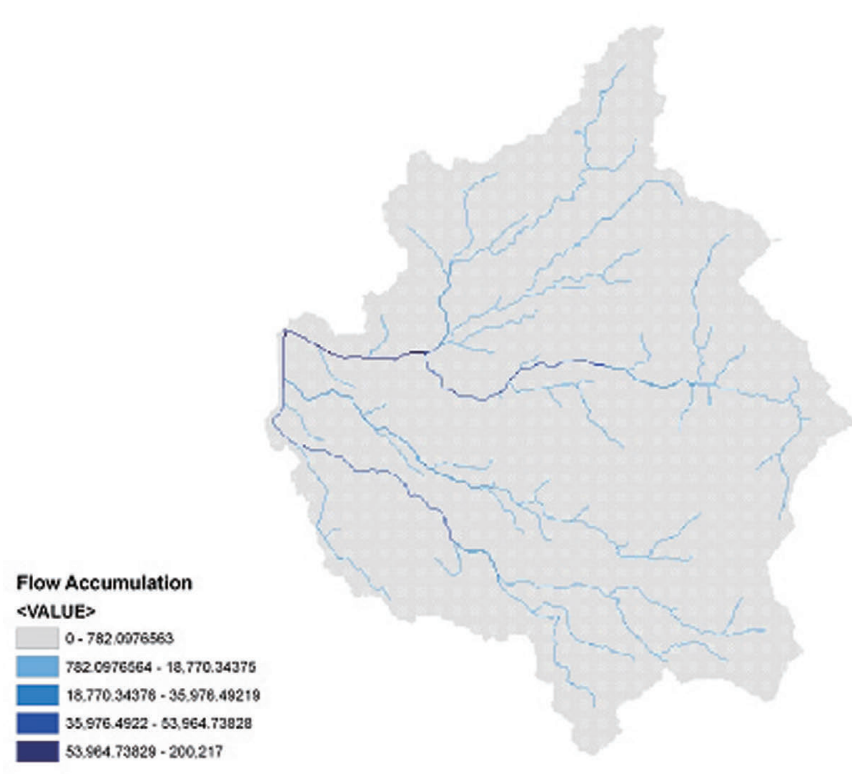

Fig. 4. Flow accumulation grid of Tatara River basin. 
for north, and, finally, 128 for northeast (Fig. 3).

Flow accumulation grid

Flow accumulation means the number of cells that drain into an individual cell in the grid and is measured in units of grid cells. The flow accumulation grid of Tatara River basin clearly defines the accumulated area of the drainage upstream at the points of the principal rivers and streams of the basin (Fig. 4).

Stream definition using a threshold drainage area

This study used the standard threshold value for stream definition of ArcHydro tools, which is $1 \%$ of the maximum flow accumulation of the basin. Selection of the smaller threshold number yields a denser stream network. However, this threshold value does not always improve the result. The smaller value may hinder or slow the speed of the catchments' delineating process (ESRI, 2006). In this case, $1 \%$ of the outlet point of 200,200 cell values is 2002 , which is equivalent to $18 \mathrm{~km}^{2}$ of the drainage area-with $30 \mathrm{~m} \times 30 \mathrm{~m}$ for each cell size. All drainage points with a smaller drainage area than $18 \mathrm{~km}^{2}$ would not be computed as stream cells and identically labeled with a value of 0 rather than 1 . Finally, the whole created stream network was then divided into distinct stream segments with unique code numbers. These stream segments are called "stream links" in ArcHydro language.

Catchments delineation

To demarcate all catchments' boundaries for each individual stream link, flow direction grid was used as the essential extracting source. Based on that, the zone of cells whose drainage flowed through each stream link was defined as a catchment and identically labeled exactly as its stream link's code.

Watershed delineation

Three options of automated watershed delineation are given in the ArcHydro data model specifically the "Batch Watershed Delineation" option under Watershed Processing utility, "Point Delineation" and "Batch Point Delineation" buttons. In this study, a representative outlet point of Tatara River basin was processed together with a point in the northern sub-watershed (Fig. 5).

\section{Drainage area characterization}

Terrain morphology utility has been attached in the ArcHydro data model, which allows drainage areas of interest in watershed research projects to be critically characterized. Height and water volume of all rivers, ponds, and lakes within Tatara River basin were obtained.

\section{Geometric Network Generation}

This process is regarded as the most overriding and significant operation of ArcHydro for terrain surface simulation and drainage network analysis. Once the geometric network has been completed, the movement of all drainage features in the basin can be clearly detected and simulated. The network consists of two main elements, which are "Hydro Junction" and "Hydro Edge". All drainage features were converted into network features with an associated geometric network created and a relationship between Hydro Junction and
Catchments was essentially constructed.

\section{Curve number and runoff models}

The curve number model has been invented to predict the level of runoff on land surface for rainfall events, as well as the condition of infiltration into soil or aquifer. A high curve number represents high runoff or low infiltration occurrence, and a low curve number indicates the opposite phenomenon (Zhan and Huang, 2004).

The SCS-CN method is based on the two fundamental assumptions (Mishra et al., 2003 and 2005). They can be expressed by the following equations as

$$
\begin{aligned}
& P=I a+F+Q \\
& \frac{Q}{P-I_{a}}=\frac{F}{S} \\
& I a=\Lambda S
\end{aligned}
$$

where $Q$ is direct runoff, $P$ is total precipitation, $I_{a}$ is initial abstraction for surface soil, $F$ is cumulative infiltration, $S$ is potential maximum retention of soil which includes various losses except for the abstraction, and $\lambda$ is a coefficient correlating $S$ with $I_{a}$. Variables are dimensional [L] quantities except for $\Lambda$, which is non-dimensional.

Using the equations (1), (2) and (3) above, the popular SCS-CN model is derived in the form

$$
Q=\frac{\left(P-I_{a}\right)^{2}}{P-I_{a}+S}
$$

The parameter $S$ in the above equation can be expressed as follows:

$$
S=\frac{25400}{C N}-254
$$

where $S$ is again the potential maximum retention of soil in $\mathrm{mm}$ and $\mathrm{CN}$ is the curve number which varies depending on land use, hydrological soil group, hydrological condition and antecedent moisture conditions (Mishra et al., 2006).

A relation between $I_{a}$ and $S$ has been given with an assumption of $\lambda=0.2$ by SCS (Hromadlka II and Yan, 1996; Terzoudi et al., 2007) as

$$
I_{a}=0.2 S(\Lambda=0.2)
$$

Elimination of $F$ and $I_{a}$ from equations (1)-(3) leads to the final relation adopted in the ArcCN-Runoff model below

$$
\begin{array}{lll}
Q=\frac{(P-0.2 S)^{2}}{P+0.8 S} & \text { If } & P>0.2 S \\
Q=0 & \text { If } & P \leq 0.2 S
\end{array}
$$

The runoff in volume for the area of interest is calculated by multiplying runoff with its area (Zhan and Huang, 2004) or 

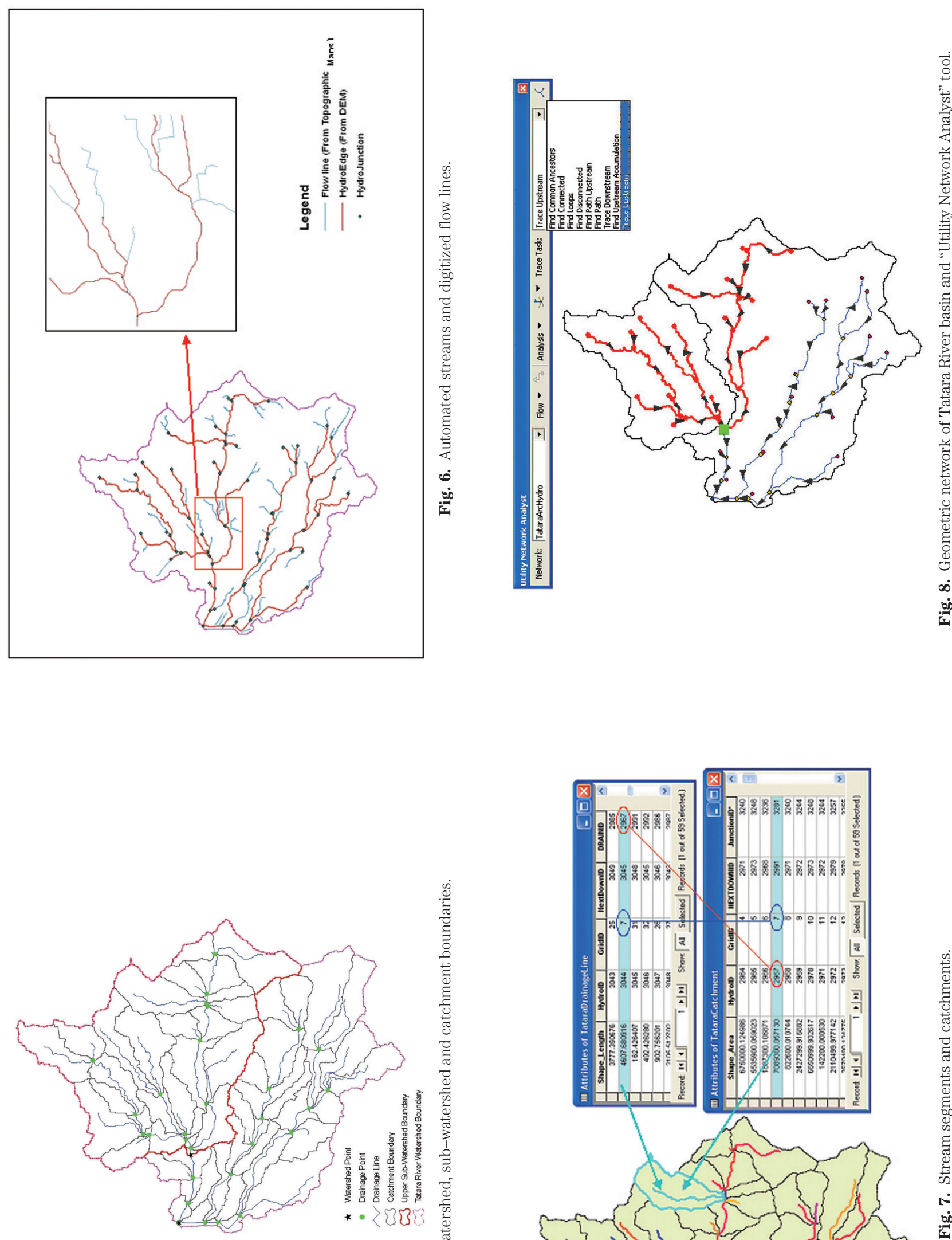

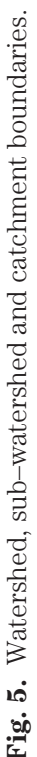

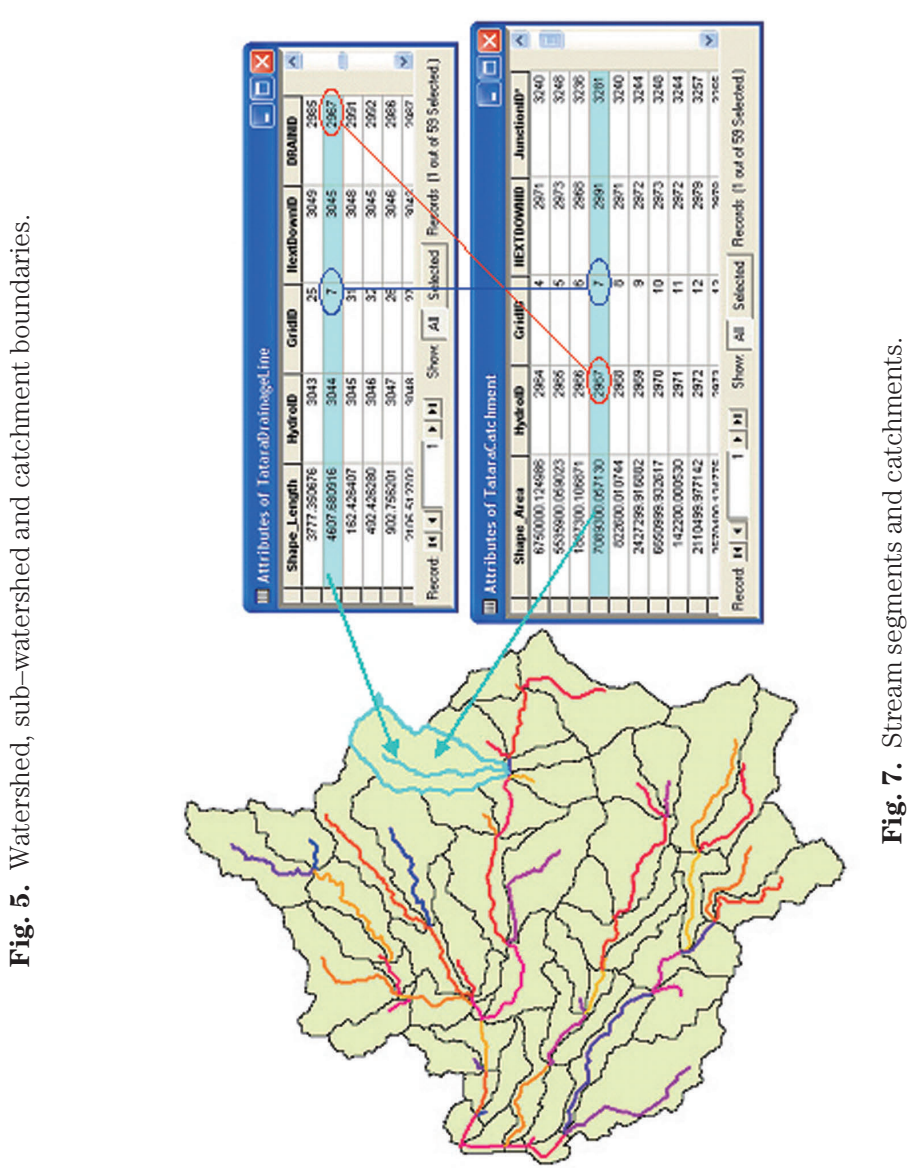



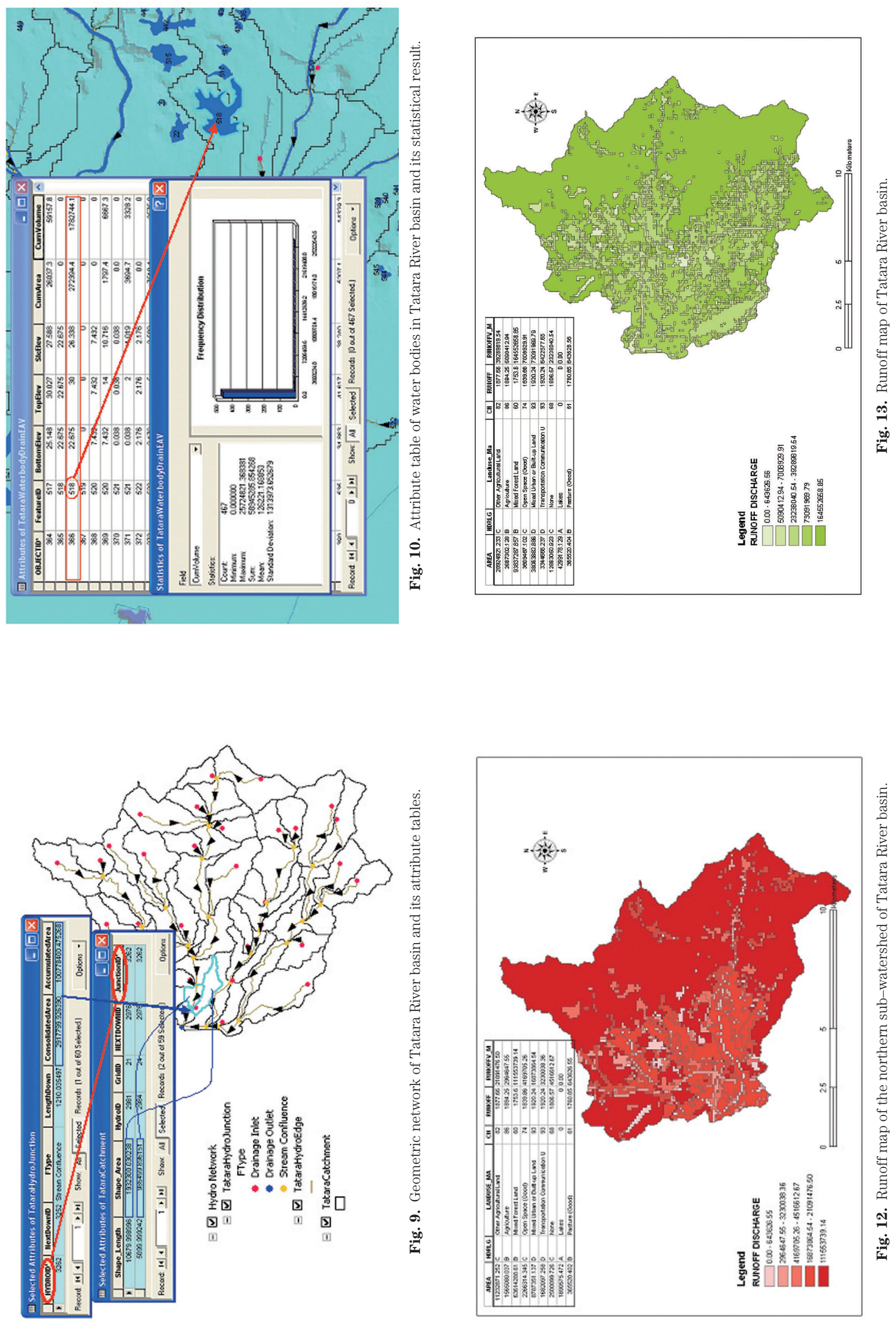


\section{Runoff Discharge $=Q \times A$}

where Runoff Discharge is in cubic meter, $Q$ is runoff in meter and $A$ is the area of watershed in square meter.

\section{RESULTS AND DISCUSSION}

Figure 6 displays a stream network derived automatically from DEM computation using the 2002 cell values mentioned above. These less dense streams give a total length of around $120,251 \mathrm{~m}$. According to the manual operation using topographic maps, the extracted streams originally have a total length of $196,887 \mathrm{~m}$. Thus, the difference between those two drainage lines is $76,636 \mathrm{~m}$.

With a total length of $120,251 \mathrm{~m}$, the drainage line extracted from DEM was divided into 59 stream segments, which responded to 59 numbers of sub-catchments in the basin. Each stream segment carries a grid ID and a drain ID (in the attribute table of "DrainageLine"), which represent the grid ID and hydro ID (as in the attribute table of "Catchment"), respectively (Fig. 7).

Once the geometric network of the whole basin is built, a relationship between "Hydro Junction" and "Catchment" can be geometrically created for the whole drainage system within the watershed area. This result enables the attribute functions of "Tracing Analyst" of ArcHydro tools, as well as "Utility Network Analyst", which allow us to analyze the drainage network in the whole region (Fig. 8). Furthermore, the Geometric Network has systematically inter-related all drainage bodies in the basin and added some significant information related to this connection such as consolidated and accumulated areas for every drainage junction, inlet, and outlet point of the catchments (Fig. 9).

Figure 10 shows the attribute table of water bodies (rivers, lakes, and ponds) and their real shapes on the map. Based on the statistic result of this figure, Tatara River basin covers some 467 hydrographic boundary features with a total cumulative water volume of about $58,945,286 \mathrm{~m}^{3}$.

The ArcCN-Runoff GIS interface extension tool, which was built based on the SCS-CN runoff model, has proved to be ideally acceptable for surface discharge calculation. We can confirm a good agreement between computed discharges and observed ones of the northern sub-watershed for the year 2001, as shown in Fig. 11. The figure also well expresses correspondence of each discharge with fluctuating amount of rainfall within the year. Figures 12 and 13 show discharge maps with attribute tables for the northern sub-watershed and the whole area of the Tatara River basin, respectively. Each map obviously gives a clear view of where the maximum or minimum runoff occurs based on gradual color with its precise value range written in the legend. Additionally, the attribute tables in the figures help us obtain information concerning $\mathrm{CN}$ used for a certain land use type, as well as the runoff in depth and discharge value with regard to its size in this study.

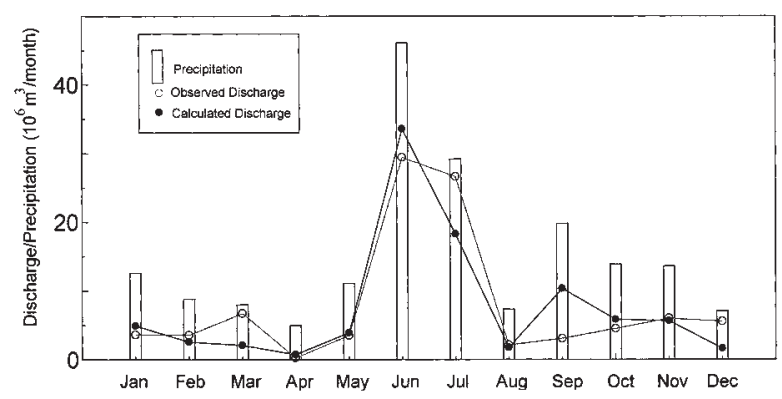

Fig. 11. Calculated and observed runoff of the northern sub-watershed of Tatara River basin in 2001.

\section{CONCLUSION}

ArcHydro GIS interface software provides a number of powerful tools that enable researchers to easily perform watershed delineation and drainage analysis in watersheds. DEM was primarily taken into account to reduce errors due to input data with low quality and naturally unavoidable mistakes of the program operation. Drainage characterization tools, including cumulative volume of lakes and rivers and even their cross sectional computation, have been practically adapted to the new version of the ArcHydro data model. A relationship among all drainage features in the basin was geometrically analyzed, and a unique code number was identically assigned to each topographic element to form a complex drainage system. This advancement has enabled us to reveal the link and connection of each particular drainage segment to its junction and catchment.

The computed result by the ArcCN-Runoff model has proved to be highly appreciated. This extension tool is found to be extremely useful, since geographical information is not easy to handle with manual calculation or even scripting programs such as FORTRAN, Visual Basic and others. Nevertheless, besides its superb capabilities, the weaknesses of this model remain as follows. Surface runoff calculation is limited to the amount of precipitation, especially on a monthly basis or longer. In addition, time series data have not been able to be operated as yet, which leads to a time consuming drawback for this program.

\section{ACKNOWLEDGEMENT}

The authors sincerely express their gratitude to River Maintenance and Flood Prevention Division, Public Works Department, Fukuoka Prefectural Government, Japan for supplying the hydro-meteorological data.

\section{REFERENCES}

Adinarayana, J., N. R. Krishna and K. G. Rao 1995 An integrated approach for prioritization of watersheds. Journal of Environmental Management, 44: 375-384

Chaubey, I., A. S. Cotter, T. A. Costello and T. S. Soerens 2005 
Effect of DEM data resolution on SWAT output uncertainty. Hydrological Processes, 18: 621-628

ESRI 2006 Arc Hydro Tool-Tutorial, Version 1.2 , 221pp

Fukuoka Citizen Bureau 2007 River information: Tatara River Map, http://bousai.city.fukuoka.jp/en/suikei1.html

Hardmeyer, K. and M. A. Spencer 2007 Using risk-based analysis and geographic information systems to access flooding problems in an urban watershed in Rhode Island. Environmental Management, 39: 563-574

Hellweger, F. 1997 AGREE - DEM Surface Reconditioning System. $\quad$ http://www.ce.utexas.edu/prof/maidment/ GISHYDRO/ferdi/research/agree/agree.html

Hromadlka II, T. V. and C. C. Yan 1996 An integrated stormwater management/GIS software system. Environmental Software, 11(4): 209-219

Jain, M. K., S. K. Mishra, P. Suresh Babu and K. Venugopal 2006a On the Ia-S relation of the SCS-CN method. Nordic Hydrology, 37(3): 261-275

Jain, M. K., S. K. Mishra and V. P. Singh 2006b Evaluation of AMC dependent SCS-CN-based model using watershed characteristics. Water Resources Management, 20: 531-552

Kenny, F. and B. Matthews 2005 A methodology for aligning raster flow direction data with photogrammetrically mapped hydrology. Computers and Geosciences, 31: 768-779

Luzio, M. D., J. G. Arnold and R. Srinivasan 2005 Effect of GIS data quality on small watershed stream flow and sediment simulations. Hydrological Processes, 19: 629-650

Lyon, J. G. 2003 GIS for Water Resources and Watershed Management. CRC Press, Boca Raton London New York Washington, D. C, 266pp.

Mack, M. J. 1995 Her - Hydrologic evaluation of runoff; the soil conservation service of curve number runoff technique as an interactive computer model. Computers and Geosciences, 21(8): 929-935

Maidment, D. R. 2002 Arc Hydro: GIS for Water Resources. ESRI Press, Redlands (CA), 218pp.

Martz, L. W. and J. Garbrecht 1992 Numerical calculation of drainage network and subcatchment areas from digital elevation models. Computers and Geosciences, 18(6): 747-761

Mishra, S. K., P. V. Singh, J. J. Sansalone and V. Aravavuthan 2003 A modified SCS-CN method: characterization and testing. Water Resources Management, 17: 37-68

Mishra, S. K., M. K. Jain, R. P Pandey and P. V. Singh 2005 Catchment area-based evaluation of the AMC-dependent SCS-CN-based rainfall-runoff models. Hydrological Processes, 19: 2701-2718

Mishra, S. K., R. K. Sahu, T. I. Eldho and M. K. Jain 2006 An improved $I_{a}-S$ relation incorporating antecedent moisture in SCS-CN methodology. Water Resource Management, 20: 643-660

Soille, P. J. and M. M. Ansoult 1990 Automated basin delineation from digital elevation models using mathematical morphology. Signal Processing, 20: 171-182

Terzoudi, Chr. B., T. A. Gemtos, N. G. Danalatos and I. Argyrokastritis 2007 Applicability of an empirical runoff estimation method in central Greece. Soil and Tillage Research, 92(1-2): 198-212

Turcotte, R., J. -P. Fortin, A. N. Rousseau, S. Massicotte and J. -P. Villeneuve 2001 Determination of the drainage structure of a watershed using a digital elevation model and a digital river and lake network. Journal of Hydrology, 240: 225-242

Zhan, X. and M. L. Huang 2004 ArcCN-Runoff: an ArcGIS tool for generating curve number and runoff maps. Environmental Modelling and Software, 19: 875-879 